\title{
Muslim Emigration to the West: The Jurisprudence of the Saudi Permanent Committee for Scholarly Research and Fatwas
}

\author{
CARLo DE ANGELO (University of Naples “L'Orientale”)
}

\begin{abstract}
Currently there are about 43 million Muslims in Europe, 20 million of whom are in the Western part of the continent. The birth of these pockets of Muslim groups is mainly due to migration, motivated essentially by economic reasons. For this reason, some Muslims turn to jurists $\left(f u q a h \bar{a}^{\prime}\right)$ to learn if the migration they intend to undertake or have already undertaken to Western countries can be considered licit (haläl) or not, under the Islamic law. For an answer to this question, some Muslims consulted the Permanent Committee for Scholarly Research and Fatwas, whose members belong to the Pietist current of the Salafi movement. The objective of this article is to analyze all the fatwas passed by such a Committee in response to questions posed. My analysis has evidenced the fact that, according to this Committee, a Muslim is obliged to reside exclusively in an Islamic territory (dār al-isläm), and forbidden to migrate to the West, due to the fact that it is considered land of the disbelievers (dār al-kufr). However, the Committee has accepted some exceptions to this rule: for example, a Muslim is allowed to migrate to non-Islamic territories to spread the word of God ( $\left.d a a^{\prime} w a\right)$, to study or to work.

Key words: Pietist Salafism, Emigration, Dār al-islām, Dār al-kufr, West, Saudi Permanent Committee for Scholarly Research and Fatwas
\end{abstract}

\section{Introduction}

The question I will try to answer in this article is the following: Is it possible for a Muslim to live in or migrate to a non-Islamic territory (e.g. the West)? The attempt here is to verify if the presence of millions of Muslims-who have chosen more or less to freely reside in Europe or in America — can be considered legal by Islamic law. In short, how does Islamic law consider their situation? Available literature has revealed that most of the studies carried out on this topic have focused on the doctrine elaborated by individual jurists or council of jurists ${ }^{1}$ who tend to favour the case that recognizes the presence of Muslims in the West as a means of improving the spread of the Islam. ${ }^{2}$ Instead, little attention has been paid to those jurists, mainly belonging to the Salafi movement, who are against the migration of Muslims to the West, in the belief that the consequence of such migration could lead to the widespread moral decadence of Muslims.

1 For example, one thinks of the European Council for Fatwa and Research; see, among others, CAEIRO 2011; LARSEN 2011; KHAN 2013; SHAVIT / ZAHALKA 2015.

2 De ANGelo 2011; De ANGelo 2013a.

Journal of Arabic and Islamic Studies 17 (2017): 204-222 (C) Carlo De Angelo, University of Naples "L'Orientale" / Italy 
Although recent Salafi jurisprudence regarding Muslim minorities has been of great interest to some scholars, ${ }^{3}$ it does not look like the research undertaken up to now has tackled the specific issue of the obligation of Muslims not to reside in the West that, according to the Pietist current of the Salafi movement, ${ }^{4}$ looms over all Muslims: "cette tendence demande aux fidèles musulmans de quitter l'Europe et l'Amerique du Nord pour des terres musulmanes'. This form of separation proposed and desired by the Salafi fuqahä' comes from the doctrine of al-walā' wa'l-barā' [loyalty (to Muslims) and disengagement (from non-Muslims)], which constitutes one of the pillars of Salafism. ${ }^{6}$ Different scholars have drawn attention to the consequences that this kind of doctrine can have on Muslims who reside in the West and adhere to this Salafi position, in terms of integration. Wagemakers, for example, affirms that 'in a Western context, al-wala' wa-l-bara' can be used as a bulwark against successful integration into society'. ${ }^{7}$ Similarly, Selim holds that, these concepts of walä' and of $b a r \bar{a}$ ' 'are deemed to be of crucial issue for Muslims living in nonMuslim countries since it has a profound impact on Muslim-non-Muslim relations ${ }^{8}{ }^{8}$ Bin Ali, is also of the same opinion, for which:

Understanding modern Salafi conceptions of Al-Wala' wal Bara' is an urgent priority in the lives of Muslims today. This understanding is critical, as Muslim increasingly live as minority communities across the globe and the concept has implications for whether (and how) Muslims can live harmoniously with non-Muslims. The consequences of applying the modern Salafi concept of Al-Wala' wal Bara' are serious - it promotes a way of life insular and hostile towards non-Muslims. [...] At the social level, Al-Wala' wal Bara' is characterised by a portrayal of non-Muslims as potential enemies, and un-Islamic practises as dangerous acts that could threaten the purity of Islam and tawhid (monotheism). ${ }^{9}$

An efficient explanation of the $a l$-wala ' wa 'l-barā' doctrine is given by Selim:

3 FARES HASSAN 2013: 19-35; SHAVIT 2015; OLSSON 2016: 108-190.

4 'S'attachant à corriger la croyance et les pratiques religieuses des musulmans, ce salafisme est convaincu que la seule solution aux problèmes de ces derniers réside dans [...] la purification et l'éducation : purifier la religion des innovations entachant ses préceptes et ses dogmes pour revenir à la religion transmise par le Prophète ; éduque les musulmans pour qu'ils se conforment à cette religion et délaissent leurs mauvaises coutumes, tout autre solution (politique ou révolutionnaire) que les détourner du droit chemin. Il s'agit bien d'insuffler aux musulmans une coscience islamique par un retour à une pratique religieuse délivrée de tout ajout postérieur à la révélation coranique et à l'apostolat prophétique. La prédication permettra de créer un mouvement social aboutissant à une nouvelle organisation du monde qui accordera à l'islam la prééminence. Ce salafisme refuse tout engagement au nom de l'islam autre que religieux'. AMGHAR 2011: 36. On Salafism and the diverse currents that animates it, see, apart from the text just cited: ROY 2004: 145-178; WIKTOROWICZ 2006: 207-239; ROUGIER 2008; MEIJER 2009; MOUSALLI 2009.

5 AMGHAR 2011: 45.

6 CAMPANINI 2015: 40.

7 WAGEMAKERS 2009: 82.

ABDOU SELIM 2015: 77-78.

BIN ALI 2015: 2. 
On the basis of [...] scriptural proofs Wala' [...] means to love Allah and to exhaust every possible means to assist His religion; it is to love those who are obedient to Him and to come for their help. Bara' [...] is to struggle against the enemies of Allah. Interpreting the concepts of Wala' and Bara' [...] and putting them into practice constitutes an essential requirement of being a good Muslim. This implementation should be conducted by heart, in terms of love and hatred, and also the entire body in terms of drawing near to Muslims and steering clear of non-Muslims. ${ }^{10}$

The strong restrictions proposed by the Salafi jurists regarding the possibility of a believer travelling to the land of the disbelievers (dār al-kufr), in primis the West, can be directly traced to the doctrine of $a l$-walà' wa'l-barā': the act of a Muslim travelling to non-Islamic territories is considered a form of wala' ' which, for the mere fact of being to non-Muslims, is considered illicit; in fact all actions a Muslim does in exercising walā' must be exclusively to his coreligionists. ${ }^{11}$

What follows in this article analyzes the prohibition on Muslims to travel to the West, as elaborated by Salafi jurists. This analysis has been added to, and published in another article in 2013. ${ }^{12}$ Unlike the latter work, whose aim was to examine the doctrine of individual jurists belonging to the Pietist current of Salafism, the current article aims at highlighting fatwas (fatāwa , sing. fatwa: non-binding opinion) passed by an organ made up of a group of persons, whose reference is the Salafi doctrine, that is the Permanent Committee for Scholarly Research and Fatwas, active in Saudi Arabia. ${ }^{13}$ Opinions expressed by this Committee have been collected in the work entitled Fatāwā al-lağna al-dā'ima li'l-buhūt al- 'ilmiyya wa'l-iftā' (from now Fatāwā al-lăgna), which is subdivided into different volumes $^{14}$ and has been my main reference for producing this article.

\section{The Rule: Muslims must reside in Islamic countries}

First, I shall try to identify to which category of territory the West (especially Europe and North America) belongs, in the opinion of the Committee, and then describe the consequences of such findings; that is, whether it is possible for a Muslim to reside in those parts of the world.

In order to achieve the main objective of this article, I shall first analyze the text with which the Lağna responded to the question of what were the necessary conditions a territo-

10 ABDOU SELIM 2015: 88.

11 FAWZÂN 2009: 323-324.

12 De ANGELO 2013b.

13 In Arabic: al-Lağna al-dā'ima li'l-buhūt al-'ilmiyya wa'l-iftā'. From now onwards alternatively, Committee or Lağna.

14 The volumes from which the fatāwa were collected, were not published in the same year by the same editor. Some of the responses have been collected directly from the Committee's website, <http://www. alifta.com/Search/Fat-waNumSrchDisplay.aspx?languagename=ar\&lang=ar >; after accessing the URL, you only need to insert the number of the fatwa, as indicated, every time, to bring up the text. All the responses were consulted in Arabic. 
ry should have to be considered non-Islamic. In the answer given to this, $\mathrm{n} .2635,{ }^{15}$ the Committee first of all provided a definition of what an Islamic territory (dār al-islām) is: all those countries (bilād, sing. balad) and territories (diya $\bar{a}$, sing dār) in which the governing body exercises its authority in respect (yuqim) of limits ( $h u d \bar{u} d$, sing. hadd) imposed by Allah and following the sharia, in which the population (ra iyya) are in the condition to fulfil (taqūm) the legal obligations of the Islamic law. Conversely, countries and territories considered non-Islamic are those whose governments (hukkām) and authorities (sulțān) rule by violating ( la yuqīm) limits imposed by Allah and refuse to keep to the rules of Islam (lā yahkumūn [...] bi-hukm al-islām). Furthermore, the Muslim who resides in this territory is denied the possibility of practising ( $l \bar{a}$ yaqwà) the prescribed acts of his/her religious faith (wāğib 'alayhi min ša 'áa'ir al-islām). Such a place is considered the territory of the disbelievers (dār al-kufr). ${ }^{16}$ From such a definition, there seems to emerge the will of the Committee to link the Islamic character of a territory to the effective application of the laws as indicated by the sharia, as well as for believers who reside within, to practise the prescribed rites of the Islamic faith. On the contrary, the number of Muslims who reside in a certain territory seems not to be an important factor to determine the status of such a territory. ${ }^{17}$ The Lağna has stated that, they should be considered $d \bar{a} r$ al-kufr even those countries (bilād), with majority of the population professing Islam, but governed by people who rule without following the divine revelation (bi-gayr ma anzal Allāh), ${ }^{18}$ and to people whose freedom of worship is not recognized. ${ }^{19}$ Overall, it is possible to affirm that the criteria used by the Committee to define the status of a territory, does not differ from those adopted by Hanbali jurists. ${ }^{20}$ According to these latter, it is to be considered dār al-islām any territory, which is under the authority of Muslims, in which Islamic rules are respected, and whose population is made up by a majority of Muslims. ${ }^{21}$ Instead, the dār al-kufr is made up of those territories in which the rules applied are that of the disbelievers. It is not relevant if there are many Muslims living inside such a territory. ${ }^{22}$ Based on the above

15 Fatāwā al-lağna 1998/1419, vol. 12: 51-54.

16 Fatāwā al-lağna 1998/1419, vol. 12: 52.

17 This idea is shared even by some Salafi who are near the Pietist current, but do not disdain a jihadi approach. For example it is believed that al-Maqdisī, according to whom: 'this term [dār al-kufr] is applied to the abode if the rulings of the kufr are uppermost, even if the majority of its people are Muslims just as the term dār alislām is applied upon the abode in which the laws of Islam are uppermost, even if the majority of its inhabitants are kuffar as long as they are submitting to the rule of Islam'. AL-MAQDISĪ, n.d.: 62. This text can be read at the following URL: <https://ia802605.us.archive.org/26/items/ThisIsOuraqidah-AbiMu-hammadAlmaqdisi/our_aqeedah.pdf $>$. For an examination of the thoughts of al-Maqdisī see WAGEMAKERS 2012.

18 According to the Committee, the authorities who operate under the conditions described above merit the term. Fatwa n. 7796, in <http://www.alifta.com/Search/FatwaNumSrchDisplay.aspx?languagename=ar\& lang $=$ ar $>$.

19 Fatāwā al-lağna 1998/1419, vol. 12: 52. However, the Committee has underlined that, Muslims who find themselves governed by a regime that does not apply the sharī ${ }^{`} a$, cannot be considered disbelievers, as long as within the limits of their possibilities, they fulfil the obligations imposed by Allah. Fatwa n. 19378, in $<$ http://www.alifta.com/Search/Fat-waNumSrchDisplay.aspx?languagename=ar\&lang=ar>.

20 For the Hanbali juristic thinking on whether a Muslim must emigrate from non-Islamic land see GERTZ 2013.

21 al-ŠAHRī 2010: 89.

22 Ibid.: 119. 
reasoning, it is possible to affirm that the West, especially Europe and America, are to be considered territories of the disbelievers.

The difference between dār al-islām and dār al-kufr as operated by the Committee serves to determine which territory can be chosen by the believer as their temporal or permanent residence. In fact, the distinctive characteristics of the dār al-islām, makes it an ideal place in which a Muslim is allowed to live (la-hum an ya $\left.{ }^{i} \bar{s} \breve{u} \bar{f} f-h \bar{a}\right) .{ }^{23}$ It is for this reason that it is compulsory for the Muslim to reside in an Islamic country (al-așl anna-hu yağibu 'alā ' $l$-muslim an yuqūm fì bilād islāmiyya $)^{24}$ even in cases in which their country of birth does not belong to them. ${ }^{25}$ The dār al-kufr, on the other hand. represents-because of its particular characteristic - a territory from which the followers of Allah should migrate (yağib 'alā 'l-muslim an yuhāğir min diyār al-kufr ilà diyār al-islām) ${ }^{26}$ and in which they should not settle, otherwise they would be committing an illicit act as agreed upon by the jurists (al-iqāma fì bilād al-kuffär muharrama $f_{i}{ }^{\prime}$ 'l-sharì'a al-islāmiyya, ${ }^{27}$ murtakib harām ${ }^{a n}$ bi'l-iğmā ). For the Committee such people will be subject to punishment and the wrath of God. ${ }^{28}$ Indeed, Muslims who have adapted to the way of life of non-Islamic territories in which they live, or simply because they admire the type of life of the place, and decide not to leave the dār al-kufr even if they have the means to do so, will be considered sinners. The same status is reserved for believers who leave the dār al-isläm for the land of the disbelievers without the real need to do so. ${ }^{29}$

It is interesting to note that the Committee never mentions an example of a country that can be considered Islamic territory, implying that this label can only be attributed to the country in which it is based, that is, Saudi Arabia.

The motive for forbidding people from settling in the dār al-kufr lies in the necessity to protect the Islamic faith and the morals of believers from being corrupted by the influence of the territory not governed by Muslims, and in which Islamic rules are not applied, ${ }^{30}$ where Muslims end up subdued or repressed $\left(m a k t u \bar{u} b^{a n} a w ~ m u g ̆ a ̄ m i l l^{a n}\right) .{ }^{31}$ For this reason,

23 Fatāwā al-lağna 1998/1419, vol. 12: 52.

24 Fatāwā al-lağna 2003/1424, vol. 19: 348.

25 Fatwa n. 19581, at <http://www.alifta.com/Search/FatwaNumSrchDisplay.aspx?languagename=ar\& lang=ar $>$. In fact, in this response the Committee urges a believer born and bred in France to migrate to an Islamic state.

26 'It is in fact an obligation on the part of a Muslim to migrate from the territory of the disbelievers towards an Islamic territory.' Fatāwā al-lağna, n.d., vol. 14: 475, fatwa n. 3859.

27 Fatwa n. 19581, at <http://www.alifta.com/Search/FatwaNumSrchDisplay.aspx?languagename=ar\& lang=ar $>$.

28 Fatwa n. 21676, at <http://www.alifta.com/Search/FatwaNumSrchDisplay.aspx?languagename=ar\& lang=ar $>$.

29 Fatāwā al-lağna 1998/1419, vol. 12: 217. Those who help others to migrate abroad are not considered sinners. Fatāwā al-lağna, n.d., vol. 15: 67-68.

30 'Limā fî'l-safar ilà bilād al-kufr min al-ḩațar alā al-'aqīda wa'l-dīn wa'l-ahlāq'. Fatāwā al-lağna 1998/1419, vol. 12: 58 (fatwa n. 19685). 'Muhāạaẓa 'alā dīnihi'. Fatāwā al-lağna, n.d., vol. 14: 475 (fatwa n. 3859). 'Li-anna hukm fî̀ tilka al-bilād gayr islāmī'. (Fatāwā al-lağna al-dā' ima li'l-buhūu al'ilmiyya wa'l-iftā' 1998/1419, vol. 12: 217 (fatwa n. 1659).

31 Fatāwā al-lağna, n.d., vol. 2: 45.

jحif • 17 (2017): 204-222 
the Lağna, based on the verses 4:97-99 ${ }^{32}$ of the Quran, has clearly and repeatedly affirmed that all Muslims who reside among disbelievers (kuffār e mušrikūn) and cannot freely practise their religion, have the obligation (wāğib) to embark on a hiğra (migration), ${ }^{33}$ that is, it is expected of them to leave the territory of the disbelievers (dār al-kufr) or the land of the polytheist (dār al-širk) for Islamic territories (dār al-islām) ${ }^{34}$ as did Muslims of the first era. Indeed these early Muslims left Mecca in $622 \mathrm{AD} / 1 \mathrm{H}$, when it was still a pagan city (dār al-kufr), ${ }^{35}$ for Medina (from Arabic madinat al-nabi, 'city of the Prophet'), ${ }^{36}$ which, after the oath of allegiance (mubāya 'a) sworn by its inhabitants to the Prophet Muhammad, had acquired the status of an Islamic territory $($ dār al-islām $) .{ }^{37}$ The specific order to migrate from Mecca to Medina was passed when the latter was first conquered by Muslims, thus making it a dār al-islām. ${ }^{38}$ This type of repeal is validated by a prophetic tradition (hadīt, pl. ahāaīt ) that says 'there is no migration after the conquest [of Mecca]' (lā hiğra ba'd alfath). ${ }^{39}$ This hadith, which has been reported by all the kutub al-sitta, repeals only the specific obligation to migrate from Mecca to Medina, while the general order to leave nonIslamic territories in favour of Islamic territories remains intact: 'fa'l-hadīt hāṣṣ bi'l-hiğra min Makka; li-annahā șārat dār al-islām, wa-ammā al-hiğra min bilād al-kufr ilà bilād almuslimīn fa-hiya bāqiya ilà qiyām al-sā'a., ${ }^{40}$ The Muslim can even leave the territory of

32 '97 Indeed, those whom the angels take [in death] while wronging themselves—-[the angels] will say, "In what [condition] were you?" They will say, "We were oppressed in the land." They [the angels] will say, "Was not the earth of Allāh spacious [enough] for you to emigrate therein?" For those, their refuge is Hell-and evil it is as a destination. ${ }^{98}$ Except for the oppressed among men, women, and children who cannot devise a plan nor are they directed to a way. ${ }^{99}$ For those it is expected that Allāh will pardon them, and Allāh is ever Pardoning and Forgiving.' The English translation of these verses is taken from The Qur'ān. English Meanings. Unless otherwise specified, all the quotations from the Quran are taken from this edition. These verses have been analyzed by different Salafi pietists; see for all, ALUȚAYMīn 1991, vol. 2: 109-122.

33 The obligation to migrate has been clearly decreed by the Committee in the following fatwas: n. 7150 (Fatāwā al-lağna 1998/1419, vol. 12: 48), n. 19670 (ibid.: 57), n. 2635 (ibid.: 52), n. 3859 (Fatāwā allağna, n.d., vol. 14: 475).

34 The Arabic terms used to describe these types of migration are: 'al-hurūğ min balad al-kufr ilà balad alislām', (Fatāwā al-lağna 1998/1419, vol. 12: 48, fatwa n. 7150); 'al-intiqāl min bilād al-širk ilà bilād alislām', (ibid.: 50, fatwa n. 9501).

35 'Hiya dār kufr, wa d̄ālika mitll makka al-mukarrama qabl al-fatḥ.' Fatāwā al-lağna 1998/1419, vol. 12: 52, fatwa n. 2635.

36 Before the migration the city of Medina was known as Yatrib.

37 Fatāwā al-lağna 1998/1419, vol. 12: 50, fatwa n. 9501.

38 Fatāwā al-lağna 1998/1419, vol. 12: 52, fatwa n. 2635.

39 Fatāwā al-lağna 1998/1419, vol. 12: 49-50, fatwa n. 5413. To analyze the above-cited tradition, see, among others, AL-'AWĀYš 1984: 99-108.

40 Fatāwā al-lağna 1998/1419, vol. 12: 260, fatwa n. 18612. In this response the members of the Committee have also hinted at other motivations that can induce the believer to migrate from (al-mufära) the territory in which he/she is, that is, to carry out a jihad (bi-sabab al-ğihād), or acquiring knowledge (al-hurūğ fí talab al- 'ilm), and finally to protect the religion from sedition (al-firär bi'l-dìn min alfitna). Regarding this last motivation, see also fatwa n. 7485 (Fatāwā al-lağna 1998/1419, vol. 12: 51). Regarding migration for the acquisition of knowledge, the Committee has observed that all Muslims are required $(w \bar{a} \bar{g} i b)$ to dedicate themselves to the study of their religion until they learn fully what Allah has imposed on them and what is forbidden to them. The importance of learning Islam is such that 
the disbelievers where he/she is residing and move to another territory of non-believers, or of polytheists, as long as this destination is less harmful (̌̌arr) and less dangerous (hatar) than the territory they are leaving. A concrete example of this type of migration can be found in the transfer of some Muslims-especially the weak-from Mecca to Abyssinia (in Arabic, Habaša), ordered by Muhammed in $614 .^{41}$ In fact, the Muslims who were involved in this transfer had received better treatment because the King of Abyssinia had recognized their religion and offered them freedom of worship and of living according to the dictates of Islam (at least what was revealed at that time), things for which they were persecuted in Mecca.

\section{Exceptions to the rule}

As we have seen, if on one hand the Committee vividly exhorts believers to do their best in abandoning non-Islamic territories in which they find themselves, ${ }^{42}$ on the other hand it does recognize an exception to the rule of the obligation of leaving the dār al-kufr, and that of migrating to it as well. In particular, those exempted from the higra are believers who are not in a condition to enable them to perform it (economic problems, sickness, etc.). For this reason, Muslims are therefore justified in residing among disbelievers; however, it is the obligation of their coreligionists to help them (e.g. supporting them economically) to migrate to countries that are secure from a religious point of view. ${ }^{43}$ An exception to the prohibition of migrating to a non-Islamic territory is acceptable in the case of a lic-

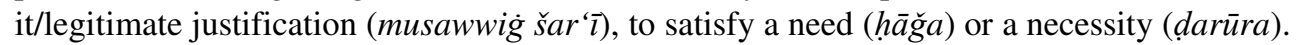
In the next sections, I analyze three specific cases for which the Committee has determined that it is possible to migrate to the dār al-kufr: to invite non-Muslims to Islam ( $\left.d a^{'} w a\right)$, in search of work, or for studies. ${ }^{44}$

the believer is ordered to move to another country (bi'l-safar min balad ilà balad) in case there is no Muslim who can guide them in acquiring such knowledge in their country. Fatāwa al-lağna 1998/1419, vol. 12: 85, fatwa n. 6575. On the obligation of the Muslim to know the basics of his religion, see also fatwa n. 8849 (Fatāwā al-lağna 1998/1419, vol. 12: 89-90).

41 Fatāwā al-lağna 1998/1419, vol. 12: 50-51, fatwa n. 9501. The migration from the city of Mecca to Abbissynia is often reffered to as the the "little higrra". LO JACONO 2003: 12-14.

42 'Wa-'alayk bi'l-iğtihād wa-baḍl al-asbāb allatī tuhalliṣuka min al-baqāa' fì bilād al-kuffār wa'l-intiqāl ilà bilād al-muslimīn' ('you are obliged to look for and to use all means to leave the land of the disbelievers and transfer to an Islamic State'), fatwa n. 19581, in <http://www.alifta.com/Search/FatwaNumSrchDisplay. aspx? languagename $=$ ar\&lang $=$ ar $>$.

43 Fatāwā al-lağna, n.d., vol. 14: 476, fatwa n. 3859.

44 Naturally, there are also other cases in which the Lagna recognizes the possibility of migrating. Undoubtedly, situations related to the necessity of having to travel to the West for medical treatment, regarding cures unavailable in Islamic countries are recognized. Fatwas n. 19581 and n. 20968, at <http://www. alifta.com/Search/FatwaNumSrchDisplay.aspx?languagename=ar\&lang=ar $>$. Another case of necessity has been identified by the Committee in response, n. 21676, in which it affirms that it is licit for the Muslim to travel (yağüz la-hu al-safar) to the dār al-kufr (specifically in Italy) to meet his/her obligation of maintaining relations with his/her relatives (șilat rahim wäğiba). The lawfulness of this case is subject to the satisfaction of three conditions: the temporary residence in the territory of the disbelievers must not be a source of temptation; his/her right to openly manifest his/her religion must be guaranteed; finally, the 


\subsection{Migration aimed at da'wa (invitation to Islam)}

Among the necessities accepted by the Committee as a valid motive for a Muslim to migrate to a non-Muslim territory is especially the $d a$ ' $w a$, or the obligation of all Muslims to invite non-Muslims to Islam. ${ }^{45}$ This is clearly declared in fatwa n. 2292, which says "whoever finds themselves in the country of the disbelievers must leave, who is not there must not go there unless for necessity like for example to carry out the da 'wa' ${ }^{46}$ Similarly in response n. 3895 it is stated that the Muslim is allowed to stay among the kuffär, when he/she in his/her function as a $d \bar{a}$ ' $\bar{l}$ (one who invites to Islam), believes he/she can influence the non-believers, convincing them to approach his/her religion. ${ }^{47}$ Thus, for a Muslim to move to the dār al-kufr with the intention of spreading Islam does not make him/her a disbeliever. ${ }^{48}$ In fact, spreading Islam in a country of disbelievers is considered a noble act (al-'amal al-ǧalìl), and the physical efforts and economic means the Muslim sustains to carry out such an act is considered a sort of jihad, for he/she shall be rewarded. ${ }^{49}$ Women must participate in this form of jihad as long as it does not distract them from their main duties, like taking care of the family. With the body duly covered, a woman can carry out the obligation of the $d a$ ' $w a$ within her family, talking to her husband, to female relatives, and to male relatives that she is forbidden to marry, ${ }^{50}$ or outside her family environment, in this case talking only to women. In the eventuality her preaching activity requires travel, she has to seek permission from and must be accompanied by her husband, or alternatively must be accompanied by a relative with whom marriage is precluded. ${ }^{51}$ Carrying out the $d a$ 'wa, which accordingly can be done in public or in secret, ${ }^{52}$ constitutes one of the necessities that justifies the verbal interaction between the $d \bar{a}^{\prime} i$ and the disbeliever, whether they are male or female. ${ }^{53}$

The Committee also, gives a number of indications to the preacher in order to make his actions fruitful. First of all the $d \bar{a}^{\prime} \bar{l}$ must have appropriate knowledge of what he/she is preaching, i.e. Islam: a Muslim who lacks this prerequisite has no title to carry out the $d a$ ' $w a$; the $d \bar{a}$ ' $\vec{\imath}$ s behaviour must be consistent with what they preach; he/she must be ex-

stay in the non-Islamic territory must be a period not exceeding the time needed to to meet the obligation for which it is admitted. Fatwa n. 21676, at <http://www.alifta.com/Search/FatwaNumSrchDisplay.aspx? languagename $=$ ar $\&$ lang $=$ ar $>$.

45 Those destined to receive the $d a$ ' $w a$ in reality include Muslims who do not respect Islamic rules and those who do respect the rules, though they intend to fortify their faith. Regarding the first case, a practical example could be those Muslims who have been under a communist regime for a long time, and have ended up completely abandoning all religious practice. Fatāwā al-lağna 1998/1419, vol. 12: 247 248, fatwa n. 3778 (on the Russians).

46 Fatāwā al-lağna 2003, vol. 20: 380

47 Fatāwā al-lağna, n.d., vol. 14: 476, fatwa n. 3859.

48 Fatāwā al-lağna, n.d., vol. 2: 47, fatwa n. 9601.

49 Fatāwā al-lağna 1998/1419, vol. 12: 260-261, fatwa n. 18612.

50 For example one thinks of the case of the convert, whose relatives remained disbelievers.

51 Fatāwā al-lağna 1998/1419, vol. 12: 34-35; 249-250, fatāwā n. 9533 and n. 4996.

52 Fatāwā al-lağna, n.d., vol. 11: 29, fatwa n. 21768.

53 Fatwa n. 19146, at <http://www.alifta.com/Search/FatwaNumSrchDisplay.aspx?languagename=ar\& lang= ar>. 
tremely patient in this activity, and must be very gentle with the disbelievers they are dealing with; finally to attract the non-Muslim to Islam, he/she must start dealing with essential questions, like that of faith. ${ }^{54}$

The execution of the $d a$ ' $w a$ has the final objective of attracting the non-Muslim to voluntarily embrace Islam. After one has been converted in Europe, in certain cases, the conversion is attested by a written certificate issued by a mosque or an Islamic centre. Some Muslims stick to the predominant idea, which indicates that for a conversion to be valid it is sufficient to have the testimony of two Muslims who have witnessed the act of conversion. These Muslims will have asked the Committee to express its opinion on the necessity of issuing the aforementioned certificate. The Committee, after having clarified that a believer does not need any document to prove his/her faith before Allah, has also affirmed that the issuing of a certificate of conversion to Islam is undoubtedly a useful instrument in identifying one's religion, especially in cases in which a believer has problems proving he/she is a Muslim. In this regard, mention is made of the case in which a Muslim travels to and dies in a place where no one knows him/her. In such a case, the lack of knowledge of the faith of the deceased becomes a problem in handling the dead body as required by Islamic rules. ${ }^{55}$

\subsection{Migration for the reason of work}

The Committee was clearly asked if, for a Muslim in search of work, it was possible to travel (al-safar) to non-Islamic countries, in the West or the East, instead of the Islamic countries with restrictive immigration laws or lack of security. It responded positively, stating that as long as the believer can practise his/her religion openly (yastați ‘ izhār dīnihi), and has no fear of temptation, it is left to him/her to evaluate the suitability or not of travelling to such a country. ${ }^{56}$ This stance is reaffirmed in another fatwa (n. 9272) in which the Committee clearly states that, a Muslim is allowed ( $\check{g} \bar{a}$ ' $i z)$ to work ('amal) in a country of disbelievers (al-duwal al-käfira) ${ }^{57}$ Similarly, in response n. 5488, the Lağna declared that nothing forbids $\left(l \bar{a} m \bar{a} n i^{\circ}\right)$ a Muslim from working in a non-Islamic country (dawla gayr muslima) as long as he/she does a work that does not imply disobedience to Allah (laysa ma șiyat Alläh) or temptation to disobey ${ }^{58}$ In the jurisprudence of the Lağna regarding this, there is some ambiguity; in fact, there are different responses in which it is against the migration to a dār al-kufr for economic reasons. In fatwa n. 19685, for example, the Committee has declared that a Muslim in search of work or means of sustenance must travel to Islamic countries (biläd al-musliminn), instead of the country of the disbelievers, where their presence could generate negative influence on their faith, morals or closeness to their religion. ${ }^{59}$ Similarly, in responding to the question of a believer who asked if he could resolve his precarious economic conditions by going to work in a foreign country, it

54 Fatāwā al-lağna 1998/1419, vol. 12: 245-257, fatwa n. 16024.

55 Fatāwā al-lağna, n.d., vol. 3: 389, fatwa n. 7212.

56 Fatwa n. 6287, at <http://www.alifta.com/Search/FatwaNumSrchDisplay.aspx?languagename=ar \&lang=ar.>

57 Fatāwā al-lağna, n.d., vol. 2: 75, fatwa n. 9272.

58 Fatāwā al-lağna, n.d., vol. 14: 479, fatwa n. 5488.

59 Fatāwā al-lağna 1998/1419, vol. 12: 58, fatwa n. 19685. 
affirmed that migration in search of work is admissible as long as it is to an Islamic country (al-bilād al-islāmiyya). ${ }^{60}$ Finally, in response n. 3859, the Lağna has stated that a Muslim who has the means to be able to transfer to an Islamic country is not permitted to remain in the dār al-kufr for the reason of occupation regardless of the fact that he/she might be an employee of a fellow Muslim or a disbeliever. ${ }^{61}$

Therefore, even if with some areas of doubt, the Lağna admits that the follower of Allah can move to the dār al-kufr where the majority of the population is made up of disbelievers for reasons of work, where he/she would most likely work for a non-Muslim, which is permissible in this case. From this point of view, the Committee has stated that nothing prevents a Muslim from being employed by a disbeliever, as long as the work he/she is asked to do is permissible (mubāh), ${ }^{62}$ that is, compatible with the prescriptions of Islam, ${ }^{63}$ and that he/she is guaranteed the freedom to practise Islam. From this point of view, fatwa n. 1832 is important, in which the Lağna responds to a Muslim worker who asked if it was licit or not (halāl am harām) to receive payment (kasb) in Germany for work done, and declares that, by rule $(a s ̦ l)$ it is permitted (hill) to employ a worker and pay them after the job has been done. Indeed, in the reasoning of the Committee, what makes the pay legitimate or not does not depend on the religion of the employer but the nature of the work in question. ${ }^{64}$ A Muslim, however, can receive payment only for a lawful work done ${ }^{65} \mathrm{re-}$ gardless of whether the employer was a Muslim or non-Muslim, ${ }^{66}$ and also irrespective of the employer being in the private or public sector (al-a'māl al-hukümiyya). ${ }^{67}$ The level of awareness of the Muslim as regarding the unlawful nature of the job decides the outcome of the compensation received for the work done. The payment can be kept in case of complete unawareness, ${ }^{68}$ otherwise the Muslim will have to forgo that money, donating it to charity for example, and doing the same with whatever might have been bought with such money. ${ }^{69}$ Notable too is response n. 4047 , which has to do with the responsibility of the

60 Fatāwā al-lağna, n.d., vol. 15: 76-77, fatwa n. 16221.

61 Fatāwā al-lağna, n.d., vol. 14: 475-476, fatwa n. 3859.

62 Ibid.: 485-486, fatwa n. 15921.

63 Fatāwā al-lağna 2003/1424, vol. 19: 348, fatwa n. 5512.

64 Instead, a Muslim cannot keep money he/she has found, in an Islamic country. He/she has to report such findings. If in case such findings happen in a non-Islamic country in conflict with Muslims, then he can keep such money found. Fatwa n. 5512, at <http://www.alifta.com/Search/FatwaNumSrchDisplay. aspx?languagename=ar\&lang=ar $>$.

65 By analogy, a Muslim can receive pension payment that he/she has eventually matured during his/her working years only if the work was licit. The Committee made this expression regarding, for example, a Morroccan who received his pension from the French government, after having worked for a number of years in France. Fatwa n. 21534, at <http://www.alifta.com/Search/FatwaNumSrchDisplay.aspx? languagename $=$ ar \&lang $=$ ar $>$.

66 Fatāwā al-lağna, n.d., vol. 14: 477-478, 437-438, fatwa n. 1832 and n. 18871.

67 Ibid.: 479, fatwa n. 5488 .

68 As it has been established by the Committee, in reference to, for example, a believer who had resigned from his job in a Saudi/Dutch bank, immediately after finding out the illicit nature of the job. Fatāwa al-lağna, n.d., vol. 15: 50-51, fatwa n. 4331.

69 The Lağna has expressed itself in this sense, regarding, for example, the case of a Somali woman who lived in Sweden. She was working as a housekeeper with a Christian family, where she sometimes had to serve wine. Fatāwā al-lağna, n.d., vol. 14: 484-485, fatwa n. 18909. The same verdict was also ex- 
employer in recognizing the right of the Muslim worker to respect obligations imposed by their religion. In this case the Lağna has declared that the Muslim is not allowed to work for a non-Muslim employer who does not allow them to carry out the daily prayers, or impedes them from praying at the prescribed times of day, and/or at the congregational prayer of Friday, a major prescribed prayer from which a Muslim cannot abstain, except in cases where it is legally admissible (such as in sickness or during travel etc.), which does not include the stay in the dār al-kufr. It is for this reason that the believer must leave their work knowing that Allah will compensate them by letting them find a better job. ${ }^{70}$ In the same way, the Committee has also forbidden the Muslim woman to work in the West (diyār al-garb) if, for example, such a circumstance prevents her from respecting the rule of wearing the veil (hig $\bar{a} b),{ }^{71}$ or from carrying out her prayers at the prescribed times $;{ }^{72}$ it has also forbidden her ( $\left.\dot{g} a y r g \bar{a}^{\prime} i z\right)$, if she works in non-Islamic countries (al-duwal $\dot{g} a y r$ al-islämiyya), from working factories or offices in which all the employees work together (ihtilatt), that is without the separation of male and female workers. ${ }^{73}$ The Committee has confirmed this position in another fatwa, n. 19504, issued in response to a question regarding the conditions of an American Muslim woman (muslima amrikiyya) who to support herself was compelled (tadtarr) to work in an environment where men and women worked together, and where she was compelled to remove her veil. To this woman, the Lağna, after reminding her that a Muslim woman was not permitted to work in a mixed environment and that she was obliged to wear the hiğāb, advised her to look for a lawful job (mubāh), in which there was nothing forbidden (harām). ${ }^{74}$

There are many responses in which the Committee has expressed its opinion regarding the type of work it considers forbidden, and which therefore cannot be done by Muslims. It has, for example, declared unlawful all jobs regarding the production, sale and distribution of alcoholic beverages and pork. For this reason, two Muslims-one working as a cook in the United States of America and the other working in a factory in France-were ordered to leave their jobs because in both cases it had to do with pork. ${ }^{75}$ Likewise, all jobs directly or indirectly related to banks whose operations are based on a system of profit are forbidden. ${ }^{76}$

In fatwa n. 19479 the Committee has held that the followers of Allah, be they male or female, cannot work in factories of disbelievers who produce arms, become part of their armies, or in general do any work that increases their military might. Engaging in such

pressed regarding the case of a Muslim who had migrated to France, where he was running a bar in which he sold alcoholic beverages. Ibid.: 65-68, fatwa n. 4047.

70 Ibid.: 478, 467-468, n. 4047 and n. 9850; fatwa n. 18100, at <http://www.alifta.com/Search/FatwaNum SrchDisplay.asp $x$ ?languagename $=$ ar\&lang $=$ ar $>$.

71 There are many responses in which the Committee has established the obligation for women to wear the veil. For all see Fatāwā al-lağna 2003, vol. 17: 248-255, fatwa n. 5168. It is interesting to underline that, according to the Lağna, a husband can ask for the break-up of the marriage if the wife refuses to wear a veil, even if she is a Christian. Ibid.: 108-109, fatwa 5089.

72 Ibid.: 235, fatwa n. 5512.

73 Ibid.: 232, fatwa n. 2768.

74 Ibid.: 231, fatwa n. 19504.

75 Ibid.: 287-288, fatwa n. 4047; Fatāwā al-lağna, n.d., vol. 14: 421 (fatwa n. 6364), 436-437.

76 Fatāwā al-lağna, n.d., vol. 15: 47-48 (fatwa n. 3546), 55-56 (fatwa n. 5317). 
activities will amount to swearing allegiance to the kuffär, or supporting them, becoming one of them unawares. ${ }^{77}$ For the Muslim, working in gay friendly hotels is also prohibited (la taǧu $\bar{u}$ ), otherwise one will be an accomplice to a forbidden act (ițm) and a transgression ('udwān, in the sense of excess). This is how the Committee, with fatwa n. 11728, responded to a Muslim who was temporarily living in Holland where he worked as a cleaner in a hotel. After discovering the hotel was gay-friendly, he consulted the Lağna to learn if he could continue doing the work, considering the difficulty of finding another job. The response was negative. $^{78}$

The question of the connection between migration to find work and family relations has been the theme of many responses of the Committee, some of which I have analyzed.

When a male married believer travels abroad for a long period of time for reasons of work, he needs the permission of his wife. Otherwise it is considered a sin (átim) to have neglected his marital duties. However, it is not considered a sin (ātim) when the Muslim departs with the blessings of his wife, or in pursuit of an objective that will benefit him and the family or the $u m m a .^{79}$ In some cases the Muslim who has passed a long period of time abroad for reasons of work, he has to ask for permission from his in-laws to enable his wife to join him. In some Islamic countries there is the habit ( ' $\bar{a} d a$ ) of including a provision (dakk) in the marriage agreement in which one agrees not to live far away from the bride's family. Questioned on this issue, the Committee responded that a Muslim husband cannot compel the parents of the wife to allow their daughter to leave; he can only try to convince them by explaining to them that living abroad for long periods of time necessitates the presence of his wife, and that her leaving will not cause her any moral or material damages. $^{80}$

The Lağna was also consulted for solution to a case involving a father who refused to allow his son to leave an Islamic country for Europe, with the objective of finding a job to support himself. The Committee recognized the difficulty in which the young man and his family found themselves, and the state of necessity that made migration lawful (la harrağa 'alā al-walad fídalika li-darūra), even against the will of the parents. The immigrant son however, has to help his parents proportionally to his earnings, providing them with money (māl) or a carer (hadim) ${ }^{81}$

Some Muslims men living in Europe for work who were passing very long periods of time far away from their wives, therefore finding themselves unable to satisfy their sexual needs, consulted the Lağna, asking if the extraordinary condition in which they find themselves could justify extramarital sexual relations, normally considered illegal. The Committee responded that it was absolutely forbidden to have such relations, even when a man was far away from the wife for many years. To find a solution to such a situation, he has to make the wife join him, and if this was not possible, to marry a second wife in that country,

77 Fatwa n. 19479, at <http://www.alifta.com/Search/FatwaNumSrchDisplay.aspx?languagename=ar \&lang $=$ ar $>$.

78 Fatāwā al-lağna, n.d., vol. 14: 430-431, fatwa n. 11728.

79 Fatāwā al-lağna 2003/1424, vol. 19: 338 (fatwa n. 606), 344 (fatwa n. 2301); 348 (fatwa n. 5512).

80 Ibid.: 346, fatwa n. 6159.

81 Fatwa n. 6582, at <http://www.alifta.com/Search/FatwaNumSrchDisplay.aspx?languagename=ar \&lang=ar $>$. 
be she a Muslim, Jew or Christian. If this last solution is not possible, then the Muslim has no option but to live a life of chastity. A helpful tool in this regard is fasting, which is well known for its collateral effect of reducing sexual desire. ${ }^{82}$

The satisfaction of the sexual needs of the Muslim migrant worker has been dealt with in another response - n. 9387. The Committee was asked to express its opinion regarding the case of a man who, after a very long period of travel for professional reasons, came home for a two-day holiday and wanted to have sex with the wife, who was in her menstrual period or had just given birth. It responded that the situation in which the Muslim finds himself does not exempt him from respecting the prescribed rules of the case in question, alternatively he can have sex with the wife as long as there is no vaginal penetration. In fact, based on the Quranic verse 2:222, ${ }^{83}$ vaginal penetration is not admitted until a definite end of bleeding, after which the woman will have to perform the necessary ablution to bring her back to a state of purity. ${ }^{84}$

\subsection{Migration for reasons of studies}

The Committee also made a declaration regarding the possibility of a Muslim traveling to the country of the disbelievers (diyār al-kufr) for the reason of studies, establishing that it should be permitted only in the case of effective necessity (lā tahull illa li'l-hâăg), and only if the level of devotion of the student is strong enough for them to withstand the dangers of being influenced negatively from a religious and moral point of view by their stay in the non-Islamic territory. ${ }^{85}$ Regarding the type of study that makes it possible to reside in a non-Islamic country, in fatwa n. $2358^{86}$ the Lağna, responding to the question 'Is it possible to travel to the U.S.A for academic reasons? ${ }^{87}$ distinguished between religious knowledge and $\operatorname{Arabic}^{88}$ (al-'ulüm al-dìniyya wa'l-arabiyya) on one hand, and the profane or mundane (al- 'ulüm al-dunyawiyya) on the other hand. There is no need to travel to the country of the disbelievers (al-duwal al-käfira) to learn the former, since this type of knowledge can be taught only by very qualified and trustworthy people (ahl al-tiqāt alma'amūnin), of which the Islamic world is full (wa dalika mutawaffir [...] fi al-duwal alislämiyya). Instead, regarding the acquisition of profane knowledge like medicine, engineering etc., the Lağna admits it is lawful to travel to the dār al-kufr, including the United States, to pursue studies, as long as three conditions are met. The first of which is that it

82 Fatāwā al-lağna 2003, vol. 22: 22-23, fatwa n. 4765.

83 "And they ask you about menstruation. Say, "It is harm, so keep away from wives during menstruation. And do not approach them until they are pure. And when they have purified themselves, then come to them from where Allāh has ordained for you. Indeed, Allāh loves those who are constantly repentant and loves those who purify themselves."

84 Fatāwā al-lağna 2003, vol. 19: 287-288, fatwa n. 9387.

85 Fatāwā al-lağna 2003, vol. 16: 220, fatwa n. 17813.

86 Fatāwā al-lağna 1998/1419, vol. 12: 137-138.

87 In Arabic "Hal yağūz al-safar ilà bilād amrīkā li’l-dirasāt?".

88 The learning of languages other than Arabic, particularly those spoken by Christians (English, German etc.), is licit ( $(\check{g} \bar{a} ' i z)$ only when it has the function of serving a religious need (hăğa al-diniyya), that is, inviting non-Muslims to Islam $\left(d a^{a} w a\right)$, or of a profane need (hăğa al-dunyawiyya), for example, for reasons of work; otherwise it is considered despicable (makrūh). Fatāwā al-lağna 1998/1419, vol. 12: 133-134, fatwa n. 4967 and n. 8864 
should be knowledge that the Muslim student cannot acquire in an Islamic country due to the lack of Muslim teachers able to teach the subject and the impossibility of importing foreign specialists to teach it. The necessity to meet the first demand-that is, courses offered in the Muslim's country of origin do not include the course for pursuit of which they are travelling to a non-Islamic state-has been dealt with by the Committee in another fatwa, n. 20968, with which it responds to a Saudi student who received a scholarship from an American university for a course that was also available in Islamic countries. The Lağna denied this student the possibility of studying in the United States because it did not see the necessity of pursuing that course there as it was available in Islamic countries. Therefore migrating in this case was unjustified. ${ }^{89}$ Meeting the second condition for which one can study abroad is related to the usefulness of the studies to the country of origin, as, for example, the creation of Muslim specialists in various fields that would free the Islamic countries from the necessity of having to bring in specialist disbelievers from abroad. ${ }^{90}$ Finally, the third condition for the believer to meet before they can travel abroad is a high level of faith and strong belief in the Islamic culture that makes them immune to any possible influence and temptation that they might encounter during their study period in a non-Islamic country. Similarly, in another response, the Committee affirms that the student who for academic reasons is compelled to migrate to a non-Islamic state (inna idțarr li-ẓurūf aḥătat bi-hi [...] ilà [...] țalab al-'ilm fì bilād gayr islämiyya raḩhaș la-hu), has the obligation to perform the prescribed rituals (wağib 'alay-hi an yuhâafaz 'alā ša 'á 'ir dīn-hi) and to respect Islamic morals, as well as meeting all the obligations of a Muslim. ${ }^{91}$ It looks like the freedom to practise one's faith is the main prerequisite for a Muslim to reside in a dār al-kufr, regardless of what their motive is for being there. This principle has been repeated constantly by the Committee; for example in fatwa n. 2922, with which it responded to a Muslim resident in Great Britain who asked if it was unlawful to live in a country where one could not make a call to prayer $(a \underline{d} \bar{a} n)$ at a high volume. ${ }^{92}$ The Lağna responded that a Muslim cannot reside in a country where they cannot openly practise their faith as prescribed, and that they have to abandon such a country for another in which their religious rights are guaranteed. This obligation to migrate is, however, valid for those believers who have the means to do so, and their refusal will amount to sinning. ${ }^{93}$ The obligation of the believer to respect the prescribed acts of faith wherever they are is also mentioned by the Committee in response n. 2635, in which it is established that a Muslim is expected to

89 Fatwa n. 20968, at <http://www.alifta.com/Search/FatwaNumSrchDisplay.aspx ?languagename=ar \&lang=ar>.

90 In the name of such functionality the Committee admits that the student can remain abroad for reasons of study even if the course they are doing obliges them to study theories such as that of Darwin, which does not agree with the principles of Islam. Fatāwā al-lağna 1998/1419, vol. 12: 139-140, fatwa n. 8152.

91 Fatāwā al-lağna 2003, vol. 19: 344, fatwa n. 2301.

92 The Muslim must be permitted to make the call to prayer (al-adadan) and also to make announcements regarding the beginning of prayer (al-iqāma) wherever they are, either in Islamic countries or $d \bar{a} r a l$ kufr. Fatāwā al-lağna undated, vol. 6: 55-56, fatwa n. 12260.

93 Fatāwā al-lağna 1998/1419, vol. 12: 54-55. 
perform the Friday congregational prayer (șalāt al-ğum 'a) even while residing in the $d \bar{a} r$ al-kufr. ${ }^{94}$

In many cases, Muslim students residing in non-Islamic countries for studies do not have the necessary means to sustain expenditure like tuition fees, acquisition of books and other study materials, feeding, housing etc. Hence they have to look for other sources of finance to meet expenditure. This finance however must be sharī a compliant ${ }^{95}$ thus, it must conform to the rules of Islam. Consequently, donations or scholarships related to banks that operate on profit cannot be accepted. ${ }^{96}$

To avoid violating the rules of Islamic law is why many Muslim students in America are not allowed to take American medical insurance, indispensable for medical treatment and taking care of general medical expenditure. The Committee holds that such an insurance is similar to commercial insurance (al-ta'min al-tiğär $\bar{l}$ ) and is considered to contain excessive risk or a gamble (al-garar al-făhiš wa'l-muqāmara), which makes it unlawful. ${ }^{97}$

Like many other students, even Muslim students sometimes cannot afford the cost of housing alone and are therefore compelled to share accommodation with other students who might belong to other religious faiths or simply be atheists. This unpleasant situation has been the subject of clarification that some students put before the Lağna, which stated that in general they should not stay with non-Muslims (lä yahull la-ka an yuqīm ma'a giayr al-muslimin); on the other hand, if this is not possible, the sharing of accommodation with a non-Muslim is allowed, as long as the Muslim student takes it upon themself to invite their housemate to Islam, both verbally and practically. For this reason they must maintain gentle behaviour to their housemate with the objective of winning them over by being gentle even when they offend Islam, and should accept and exchange invitations to eat together. ${ }^{98}$ On the possibility of offering food to non-Muslims specifically, the Committee has clarified an important issue of Islamic law: 'The qualification of an action depends on the objective of that action, and vice versa.' To put it more clearly, if it is obligatory to achieve a certain objective, the action that leads to achieving that objective becomes obligatory too

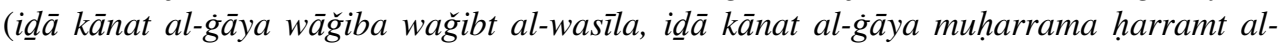
wasila). As mentioned above, to offer food to the non-Muslim is considered licit, because it has the intended objective of attracting someone to Islam $\left(d a^{\prime} w a\right)$. Obviously the food

94 Fatāwā al-lağna 1996, vol. 8: 186.

95 From this point of view, it is interesting to note how the necessity for the Muslim student to finance their studies by taking a loan that conforms to Islamic rules (sharī $a$ compliant) has induced the British government to consult experts on Islamic finance to find an alternative solution to the traditional system of loans, an option that 'meets the needs of students who believed that a student loan was incompatible with their beliefs'. In this regard, it wanted 'to hear from Muslims about the acceptability of the finance product, since it is important that any sharia-compliant finance product is transparent, understandable and acceptable to the majority of students who might wish to apply for a finance of this type'. DEPARTMENT FOR BUSINESS INNOVATION AND SKILLS, n.d.: 5.

96 Fatāwā al-lağna 1998/1419, vol. 12: 151-152, fatwa n. 16184.

97 Fatāwā al-lağna, n.d. vol. 15: 296-297 (fatwa n. 7723), 307-310 (fatwa n. 16048); <http://www.alifta. $\mathrm{com} /$ Fatawa/FatawaChapters.aspx ?languagename $=$ en $\&$ View $=$ Page \&PageID=392\&PageNo=1\&BookI $\mathrm{D}=17>$. On the possibilities of Muslims in the West to sign insurance contracts, see: ZARABOZO, n.d.

98 Fatwa n. 14091 and n. 2165, in <http://www.alifta.com/Search/FatwaNumSrchDisplay.aspx?language-name $=$ ar\&lang=ar $>$.

jحis • 17 (2017): 204-222 
offered must be halāl, and if it is in Ramadan the food must be offered during the hours it is permitted to eat. ${ }^{99}$ Food is the theme of another question posed by some Muslim students in America, who asked the Committee if it was lawful to eat locally produced meat (lahm, pl. luhum). Basing on verse 5:5 of the Quran, ${ }^{100}$ the Lağna stated that according to the general rule, a Muslim can eat the meat of an animal slaughtered by Christians and Jews (People of the Books) as long as it is an animal which is lawful according to the shari' $a$ (camels, cows sheep, chicken etc.). On the contrary, the meat of an animal slaughtered by disbelievers (kuffār), for example pagans (wataniyyīn), by atheists (man lā dīn lahum) and communists ( $\breve{s} u \bar{u}$ 'iyyinn) cannot be eaten. Regardless of the general rule cited here by the Committee, it also advises against eating meat sold in the US, especially in cases in which the believer has doubts whether Islamic rules regarding slaughter have been applied. ${ }^{101}$ In another response, however, the Lağna has softened its position. It affirmed that it is forbidden to eat meat or cheese to which the fat or blood of pork has been added, as long as such addition is certain. Instead, in case of doubt such meat can be eaten. ${ }^{102}$ The rule is that whatever food is to be considered licit can be eaten, until and unless there is concrete proof that there is something that renders it illicit. ${ }^{103}$

The Lağna has also talked about the case in which a Muslim student's stay with a nonMuslim is not for economic reasons but for the sake of improving their skills in the language of the non-Muslim. The Committee was consulted on the issue of students residing with an American family regarding the immense advantage for the Muslim students in acquiring practical knowledge of the English language. It responded by saying that it is better for the Muslim to live with other Muslims, and stay as far away as possible from disbelievers regardless of their nationality, since this is the only way they can preserve their religion and morals. In fact proximity to non-Muslims is considered a source of temptation that can induce the Muslim to take the wrong path. It is for this reason that the Committee has established that it is unlawful for a Muslim to live in a family of disbelievers, especially when such a family contains women, because their limited sense of morals can become a serious temptation to the rectitude of the Muslim. Finally, practising the language is not enough of a necessity to justify cohabitation with the disbeliever. ${ }^{104}$

For Muslim students studying in Western countries, another fatwa was passed by the Committee-n. 21052—regarding the academic robes (rüb) worn in some European and American universities on graduation day, during the formal ceremony in which students

99 Fatāwā al-lağna, n.d., vol. 14: 474, fatwa n. 1850.

100 'This day [all] good foods have been made lawful, and the food of those who were given the Scripture is lawful for you and your food is lawful for them. And [lawful in marriage are] chaste women from among the believers and chaste women from among those who were given the Scripture before you, when you have given them their due compensation, desiring chastity, not unlawful sexual intercourse or taking [secret] lovers. And whoever denies the faith-his work has become worthless, and he, in the Hereafter, will be among the losers.'

101 Fatāwā al-lağna 2003, vol. 22: 411-412 (fatwa n. 19658), 417-418 (fatwa n. 18941), 451-452 (fatwa n. 21341). In another response (n. 3262), the Committee affirms that it is permitted to eat food offered by Christians as long as it is licit and its 'statute is known'. (Fatāwā al-lağna undated, vol. 2: 75).

102 Fatāwā al-lă̆na 2003, vol. 22: 117-118, fatwa n. 3448.

103 Ibid.: 399-400, fatwa n. 3262

104 Fatāwā al-lağna 1998/1419, vol. 12: 139, fatwa n. 2358. 
receive their diplomas or degrees. According to the Lağna, such practice is unacceptable (la tağ $\bar{u} z$ ) because this robe worn by the students is considered typically Christian (min albisat al-nașāra $\bar{a}$ ) and could end up violating the Islamic rule that forbids Muslims from imitating disbelievers (Christian, Jews, etc.). ${ }^{105}$

\section{Conclusion}

The analyses of the responses issued by the Committee confirm results arrived at by other sources. ${ }^{106}$ For instance, according to Salafi Pietists, the Muslim has been forbidden from residing in a non-Islamic country. The consequent dangers of such an action are the undermining of their religion and morals. The possibility of residing in the territory of the disbelievers is allowed only in special cases, in which there is an effective necessity such as medical treatment, work, study etc. The stay in the dār al-kufr with the objective of meeting the demands mentioned above must, however, respect a series of rules such as the freedom to practise Islamic rituals, limiting contact with the disbelievers to only those occasions when trying to convert them to Islam $\left(d a^{i} w a\right)$, without ever developing strong relations with them or criticizing them openly without offending.

All the above circumstances combine to explain why the tendency to isolate themselves can be seen among Muslim communities in the West who make reference to Salafi Pietist doctrine.

\section{Bibliography}

\section{Sources}

al-LAĞNA al-DĀ'IMA LI'L-BUHŪT AL-'ILMIYYA WA'L-IFTĀ'. No date. Fatāwāa al-lağna al-dā'ima li'lbuḥūt al- 'ilmiyya wa'l-iftā'. Riyāạ: Dār al-Mu'ayyid li'l-Našr wa'l-Tawzī', vol. 2.

—. No date. Fatāwāa al-lağna al-dā'ima li'l-buhūt al- 'ilmiyya wa'l-iftā'. No place: No publisher, vol. 3.

—. No date. Fatāwāa al-lağna al-dā'ima li'l-buhūt al- 'ilmiyya wa'l-iftā'. No place: No publisher, vol. 5.

—. No date. Fatāwā al-lağna al-dā'ima li'l-buhūt al-'ilmiyya wa'l-iftà'. No place: Dār al-'Āṣima li'l-Našr wa'l-Tawzī', vol. 6 .

— . 1996/1416. Fatāwā al-lağna al-dā'ima li'l-buhūt al-'ilmiyya wa'l-iftā'. Riyāḍ: Dār al-'Āṣima li'l-Našr wa'l-Tawzī', vol. 8.

— . No date. Fatāwā al-lağna al-dā'ima li'l-buhūt al-'ilmiyya wa'l-iftā'. Riyāḍ: Dār al- 'Āṣima li'lNašr wa'l-Tawzī', vol. 11.

105 Fatāwā n. 21052, 1620, 2301, 2358, in <http://www.alifta.com/Search/FatwaNumSrchDisplay.aspx? languagename $=$ ar\&lang $=a r>$. For some examples of actions carried out by the disbelievers, and which must not be imitated by Muslims, see response n. 4566, in <http://www.alifta.com/Search/FatwaNum SrchDisplay.aspx?languagename=ar\&lang=ar $>$. For example, the Committee, considering the cold weather characteristic of British winters, has recognized the necessity for Muslims who reside in Great Britain to sometimes shorten their hair, to facilitate its easy washing and drying. However, the same possibility should not be granted to those Muslims who want to have short hair only for the reason of imitating the hairstyles of the local disbelievers. Fatāwā al-lağna undated, vol. 5: 182, fatwa n. 2922.

106 DE ANGELO 2013b.

jais • 17 (2017): 204-222 
— . 1998/1419. Fatāwā al-lağna al-dā'ima li'l-buhūt al- 'ilmiyya wa'l-iftā' al-dā'ima li'l-buhūt al'ilmiyya wa'l-iftā'. Riyāḍ: Dār al- 'Āṣima li'l-Našr wa'l-Tawzī', vol. 12.

—. No date. Fatāwāa al-lağna al-dā'ima li'l-buḥūt al-'ilmiyya wa'l-iftā'. Riyāọ: Dār al-Mu'ayyid li'l-Našr wa'l-Tawzī', vol. 14.

—. No date. Fatāwā al-lağna al-dā'ima li'l-buḥūt al-'ilmiyya wa'l-iftā'. Riyāḍ: Dār al-Mu'ayyid li'l-Našr wa'l-Tawzī', vol. 15.

— . 2003/1423. Fatāwā al-lağna al-dā'ima li'l-buhūt al-'ilmiyya wa'l-iftā'. Riyāḍ: Dār al-Mu'ayyid li'l-Našr wa'l-Tawzī', vols. 16, 17, 19, 20, 22.

\section{Secondary literature}

Abdou Selim, Ali Shehata. 2015. The Concept of Coexistence in Islamic Primary Sources. An Analytical Examination. Newcastle: Cambridge Scholars Publishing.

AMGHAR, Samir. 2011. Le salafisme d'aujourd'hui. Mouvements sectaires en Occident. Paris: Michalon Éditions.

al- 'AwAYs, Husayn bin 'Awda. 1984. Al-faṣl al-mubīn fī mas'alat al-hiğra wa mufāraqat al-mušrikīn, Bayrūt: Dār Ibn Ḥazm.

BIN ALI, Mohamed. 2015. Forging Muslim and Non-Muslim Relationship: Contesting the Doctrine of Al-Wala' wal Bara', RSIS Commentary, No. 251.

CAEIRO, Alexandre. 2011. "Transnational ulama, European fatwas, and Islamic authority. A case study of the European Council for Fatwa and Research". In: VAN BRUINESSEN / ALLIEvi (eds.) 2011: 121-141.

CAMPANINI, Massimo. 2015. "Salafismo e islamismo nel pensiero politico islamico contemporaneo". In GuAZZONE (ed.) 2015: 40.

De ANGelo, Carlo. 2011. "L'adattamento del diritto islamico alle realtà occidentali. La nascita e i primi sviluppi del diritto delle minoranze musulmane". Studi Magrebini, 9: 65-111.

- .2013a. "The Image of Europe and the Role of its Muslims, as Portrayed in the Contemporary Islamic Debate on Muslim Minorities". Journal of Muslims in Europe, 2.2: 186-207.

—. 2013b. "From Dār al-Islām to Dār al-Kufr: Muslim Emigration to the West According to Salafi Jurisprudence". Studi Maǵrebini, 11: 95-120.

DePARTMENT For Business InNOVATION AND Skills. 2014. Shariah-Compliant Student Finance. Consultation on a Sharia-compliant alternative finance product: $<\mathrm{https} / / / \mathrm{www} . g o v . u k / g o v e r n m e n t /$ uploads/system/uploads/attachment_data/file/303423/bis-13-1311-consultation-on-a-shariacompliant-alternative-finance-product.pdf $\geq$ (accessed June 2017).

Fares Hassan, Said. 2013. Fiqh al-Aqalliyyāt. History, Development and Progress. New York: Palgrave.

FAwZĀN, Salihh. 2009. Guide to Sound Creed. A Book on Muslim Creed and Faith. Ryadh: AlMaiman Publishing House.

GERTZ, Steven. 2013. "Permission to Stay in "Enemy" Territory? Hanbali juristic thinking on whether Muslims must emigrate from non-Muslim lands". The Muslim World, 103: 94-106.

GuAzzone, Laura (ed.). 2015. Storia ed evoluzione dell'islamismo arabo. I Fratelli Musulmani e gli altri. Milan: Mondadori.

Hellum, Anne / SARDAR Ali, Shaheen / Griffiths, Anne (eds.). 2011. From Transnational Relations to Transnational Laws. North European Laws at the Crossroads. Farnham and Burlington: Ashgate.

KHAN, Adil Hussain. 2013. "Creating the Image of European Islam: The European Council for Fatwa and Research and Ireland". In: NIELSEN (ed.). 2013: 215-238.

LARSEN, Lena. 2011. "Islamic Jurisprudence and Transnational Flows: Exploring the European Council for Fatwa and Research". In: Hellum / SARDAR Ali / GRIFFITHS (eds.) 2011: 139-163.

al-MAQDisī, Abū Muḥammad 'Āṣim. No date. This is our 'aqīda. No Place: No publisher. 
MeIJeR, Roel (ed.). 2009. Global Salafism. Islam's New Religious Movement. London: Hurst \& Company.

MousalLI, Ahmad. 2009. Wahhabism, Salafism and Islamism: Who is the Enemy? Conflicts Forum, Beirut / London / Washington.

NielSEN, Jørgen S. (ed.). 2013. Muslim Political Participation in Europe. Edinburgh: Edinburgh University Press.

Roy, Olivier. 2004. L'Islam mondialisé. Paris: Éditions du Seuil.

Olsson, Susanne. 2016. Minority Jurisprudence in Islam. Muslim Communities in the West. London and New York: I.B.Tauris.

Rougier, Bernard (éd.). 2008. Qu'est-ce que le salafisme? Paris: Presses Universitaires de France.

al-ŠAHRI, Mulfī bin Ḥasan. 2010. Haqīqat al-darāyn. Dār al-islām wa'l-dār al-kufr. No place: Dār alMurābițīn.

Shavit, Uriya. 2015. Sharī‘ a and Muslim Minorities. The wasați and salafì approaches to fiqh alaqalliyyāt al-Muslima. Oxford: Oxford University Press.

Shavit, Uriya / ZaHAlKA, Iyad. 2015. "A religious law for Muslims in the West: the European Council for Fatwa and Research and the evolution of the fiqh al-aqalliyyat al-muslima". In TOTTOLI (ed.) 2015: 365-377.

The Qur'ān. English Meanings, English Revised and Edited by Șaḥeeh International. Jeddah: AlMuntada Al-Islami, 2004

TotToli, Roberto (ed.). 2015: Routdlege Handbook of Islam in the West. London and New York: Routdlege.

al-UṬAYMīn, Muḥammad bin Șāliḥ. 1991. Tafsīr al-qur'ān al-karīm: sūrat al-nisā'. Riyāḍ: Dār Ibn al-Ğawzī, 2 vols.

van Bruinessen, Martin / Allievi, Stefano (eds.). 2011. Producing Islamic Knowledge. Transmission and dissemination in Western Europe. London and New York: Routdlege.

WAGEMAKERS, Joas. 2009. "The Transformation of a Radical Concept. Al-wala' wa-l-bara' in the Ideology of Abu Muhammad al-Maqdisi”. In MeIJeR (ed.) 2009: 81-106.

- . 2012. A Quietist Jihadi. The Ideology and Influence of Abu Muhammad al-Maqdisi. New York: Cambridge University Press.

WikTorowicz, Quintan. 2006. "Anatomy of the Salafi Movement". Studies in Conflict \& Terrorism, 29.3: 207-239.

ZARABOZO, Jamaal al-Din. The Question of Insurance Outside of the "Lands of Islam": <http://www. jamaalzarabozo.com/audio/insurance.pdf> (accessed June 2017).

(c) Carlo De Angelo, University of Naples "L'Orientale" / Italy ४ carlodeangelo@yahoo.it; cdeangelo@unior.it 